Images in...

\title{
Lymphadenopathy and hepatosplenomegaly in a patient with acute myelogenous leukaemia
}

Kota Sato, Michihiro Uchiyama

Department of Hematology, Suwa Red Cross Hospital, Suwa, Japan

Correspondence to Dr Michihiro Uchiyama, mi.uchiyama@suwa.jrc.or.jp

\section{DESCRIPTION}

An 18-year-old man was admitted to our hospital with fever and generalised lymphadenopathy in October 2010. One month prior to admission, a submaxillary nodule appeared, with gradually progression to nodes involving the entire body. His medical history was unremarkable, and he was not receiving any medication. Physiological parameters were: body temperature, $37.7^{\circ} \mathrm{C}$; heart rate, 96 beats/min and regular; and blood pressure, 143/72 $\mathrm{mm} \mathrm{Hg}$. Physical examination revealed generalised enlargement of
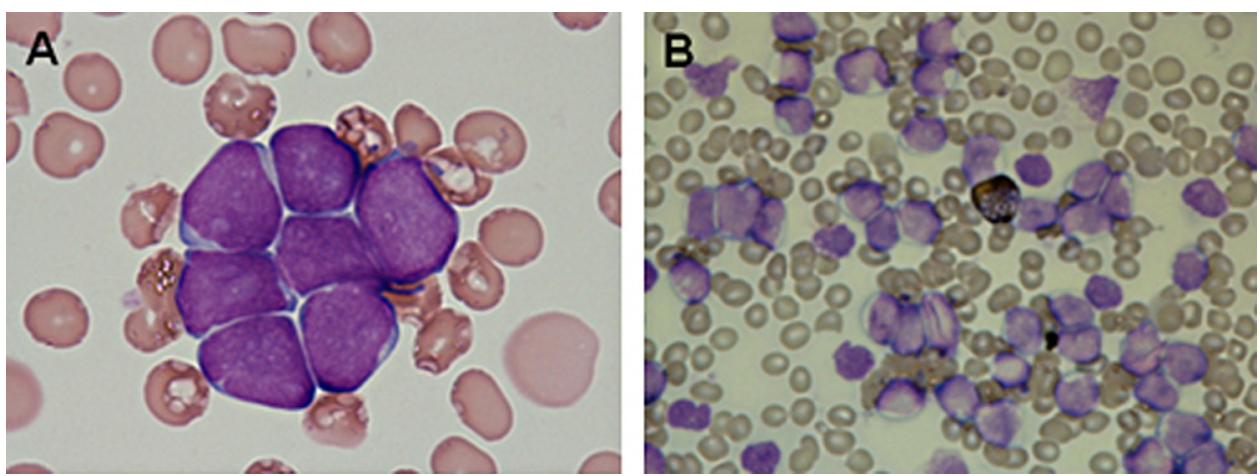

Figure 1 Bone marrow examinations at initial diagnosis (A May-Giemsa stain, 1000×: B Myeloperoxidase stain, 400×)
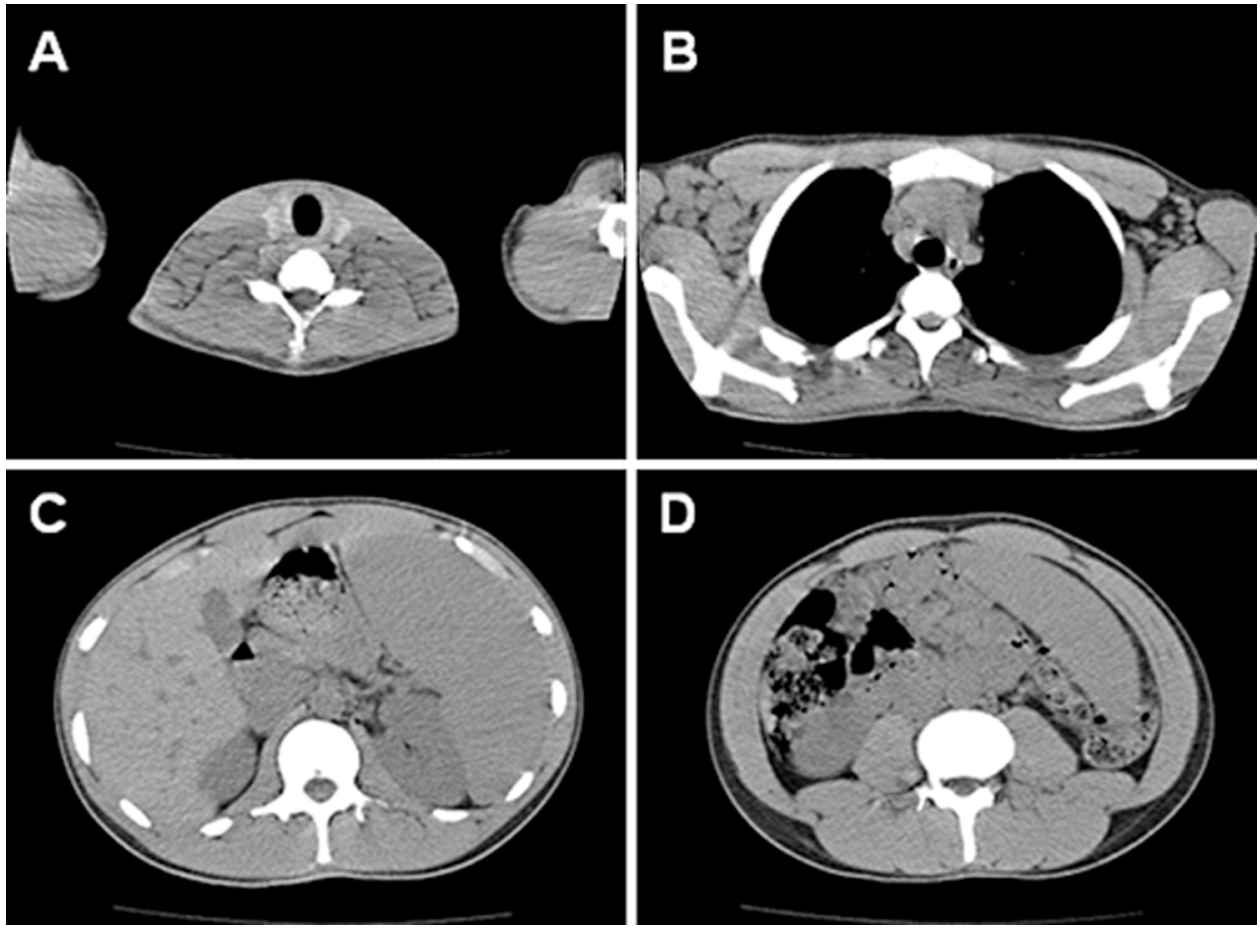

Figure 2 CT at initial diagnosis. 


\section{BMJ Case Reports}

superficial lymph nodes, varying in size from about 1 to $2 \mathrm{~cm}$. Hepatosplenomegaly was identified. Blood analyses showed a white blood cell count of $364800 / \mu 1$ with $99.8 \%$ blasts, a haemoglobin level of $13.4 \mathrm{~g} / \mathrm{dl}$ and a platelet count of $331 \times 10^{3} / \mu 1$. Biochemical analysis showed a serum lactate dehydrogenase level of 854 IU/1 (normal 101-213 IU/1). Bone marrow was hypercellular, with diffuse infiltration of undifferentiated myeloperoxidase-negative blasts (66\%) (figure 1). Blastic cells were positive for CD4, CD7, CD13, CD33, CD34 and HLA-DR on immunophenotyping analysis. These results led to a diagnosis of acute myelogenous leukaemia M0 according to the French-American-British classification. Cytogenetic analysis of blastic cells revealed 46,XY,t(10;11)(p12;q14) (20/20), and molecular analysis also showed clonal immunoglobulin gene rearrangements. ${ }^{1}$ CT revealed systemic lymphadenopathy both superior and inferior to the diaphragm, and marked enlargement of the spleen (figure 2). The patient underwent induction chemotherapy with idarubicin $\left(12 \mathrm{mg} / \mathrm{m}^{2}\right.$, days $\left.1-3\right)$ and cytosine arabinoside $\left(100 \mathrm{mg} / \mathrm{m}^{2}\right.$, days $\left.1-7\right)$. Rapid regression of lymphadenopathy and hepatospleomegaly was observed after chemotherapy and complete remission was achieved.

\section{Learning points}

- Skin, gingiva, gastrointestinal tract and central nervous system may often be associated with extramedullary involvement in the setting of AML. Granulocytic sarcoma is also a tumour composed of myeloblasts or monoblasts, and may be found in virtually any location, but is usually localized. Such prominent generalised lymph node involvement combined with hepatosplenomegaly as in this case is extremely rare in $\mathrm{AML}$ at onset, in contrast to acute lymphoblastic leukaemia (ALL).

- Moreover, the translocation $t(10 ; 11)(p 12 ; q 14)$, which results in fusion of the clathrin assembly lymphoid myeloid leukaemia (CALM) gene with the AF10 gene, was found in this case. CALM-AF10 fusions have been observed as a rare but recurring phenomenon in patients with ALL rather than AML, and are often associated with poor prognosis. ${ }^{1}$ Extramedullary involvement is a typical characteristic among patients with this translocation.

\section{Competing interests None.}

Patient consent Obtained.

\section{REFERENCES}

1. Caudell D, Aplan PD. The role of CALM-AF10 gene fusion in acute leukemia Leukemia 2008;22:678-85.

This pdf has been created automatically from the final edited text and images.

Copyright 2011 BMJ Publishing Group. All rights reserved. For permission to reuse any of this content visit http://group.bmj.com/group/rights-licensing/permissions.

BMJ Case Report Fellows may re-use this article for personal use and teaching without any further permission.

Please cite this article as follows (you will need to access the article online to obtain the date of publication).

Sato K, Uchiyama M. Lymphadenopathy and hepatosplenomegaly in a patient with acute myelogenous leukaemia. BMJ Case Reports 2011; 10.1136/bcr.10.2011.4997, Published XXX

Become a Fellow of BMJ Case Reports today and you can:

- Submit as many cases as you like

- Enjoy fast sympathetic peer review and rapid publication of accepted articles

- Access all the published articles

- Re-use any of the published material for personal use and teaching without further permission

For information on Institutional Fellowships contact consortiasales@bmjgroup.com

Visit casereports.bmj.com for more articles like this and to become a Fellow 